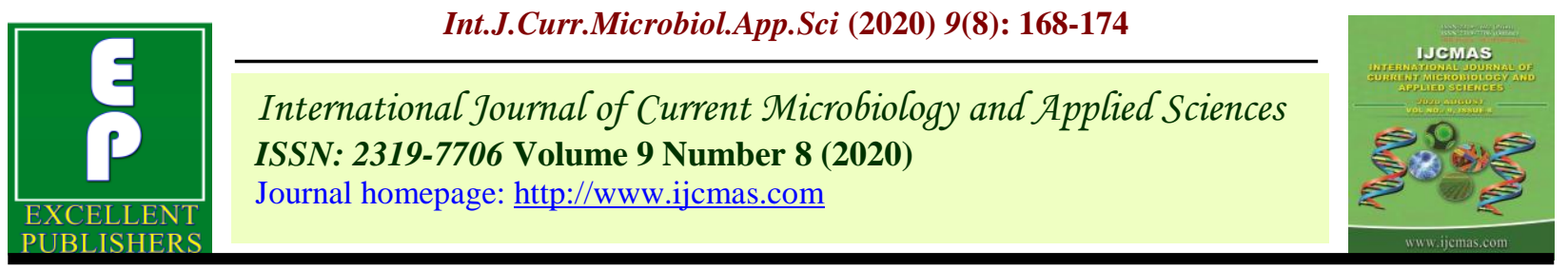

Original Research Article

https://doi.org/10.20546/ijcmas.2020.908.018

\title{
Correlation and Path Coefficient Studies for Kernel Yield and Component Traits in Maize
}

\author{
S. Mallikarjuna ${ }^{1 *}$, V. Roja ${ }^{1}$, I. Sudhir Kumar ${ }^{2}$ and T. Srinivas ${ }^{1}$ \\ ${ }^{1}$ Department of Genetics and Plant Breeding, Agricultural College, Bapatla 522 101, \\ Guntur District, Andhra Pradesh, India \\ ${ }^{2}$ Agricultural Research Station, Peddapuram, East Godavari District, Andhra Pradesh, India \\ *Corresponding author
}

\begin{abstract}
A B S T R A C T

\begin{tabular}{|l|}
\hline Ke y w o r d s \\
Maize, Correlation, \\
Path Analysis
\end{tabular}

Correlation and path coefficient analysis for kernel yield and yield components was under taken in 49 maize inbred lines using simple lattice design with two replications during kharif, 2018 at Agricultural Research Station, Peddapuram, East Godavari district, Andhra Pradesh in order to understand the relationship between kernel yield and its component traits. The studies revealed significant and positive association of kernel yield plant ${ }^{-1}$ with cob length, cob girth and cob yield plant ${ }^{-1}$ at both phenotypic and genotypic levels. The path analysis revealed high positive and direct effect of cob yield plant ${ }^{-1}$ for kernel yield plant $^{-1}$ in addition to strong positive association with kernel yield per plant indicating its true relationship with kernel yield plant $^{-1}$ Considering the nature and quantum of trait associations and their direct and indirect effects, cob yield plant ${ }^{-1}$ is identified as important selection criteria for effecting kernel yield improvement in maize.

\section{Introduction}

Maize is one of the most important crop belonging to the family Poaceae. In India, maize is grown throughout the year in most of the states. It is grown for both human as well as animal consumption. For producing high yielding genotypes in maize, selection based on yield alone is not useful because yield is a complex and polygenic character resulting from multiplicative interaction of its component traits. The cumulative effect of component traits determines yield and plays an important role in modification of yield as a whole in magnitude as well as in direction.

Therefore, correlation studies are of considerable importance in any selection programme as they provide information on the degree and direction of relationship between two or more component traits. Besides this, path coefficient analysis is also important because it provides an effective means of estimating the direct and indirect effects of the independent variables on the dependent variable and permits a critical examination of the specific forces acting to produce a given correlation and measures the relative importance of each factor. Keeping these points in view the present investigation was carried out to estimate the character
\end{abstract}


association and path coefficients for yield and its component traits.

\section{Materials and Methods}

The present investigation was carried out at Agricultural Research Station, Peddapuram, East Godavari district, Andhra Pradesh during kharif'2018. The experimental material comprised of 49 elite maize inbred lines. The genotypes were evaluated using simple lattice design with two replications and data was recorded for 14 traits, namely days to 50 percent tasseling, days to 50 percent silking, anthesis silking interval, days to maturity, plant height $(\mathrm{cm})$, ear placement height $(\mathrm{cm})$, cob length $(\mathrm{cm})$, cob girth $(\mathrm{cm})$, number of kernel rows per cob, number of kernels per row, cob yield per plant (g), kernel yield per plant (g), 100 kernel weight (g) and protein content $(\%)$ on five randomly selected plants, for each genotype, from each entry, in each replication.

Correlation coefficients were calculated at genotypic and phenotypic level using the formulae suggested by Falconer (1964) and path analysis was carried out as per the suggestions of Dewey and Lu (1959). The path coefficients were categorized as high, moderate and low based on the recommendations of Lenka and Mishra (1973). The statistical software used for analysis of the data is Statistical Analysis Software (SAS) 9.2 version and Windostat 9.1.

\section{Results and Discussion}

\section{Correlation coefficient}

The estimates of genotypic and phenotypic correlation coefficients for yield and yield components are presented in Table 1. The results revealed phenotypic and genotypic correlation coefficients to be of similar direction and significance in general. However, the phenotypic coefficients were observed to be of lower magnitude in general, compared to genotypic coefficients, indicating the masking effect of environment. The findings are in agreement with the reports of Lokeshwar Reddy et al., (2018). The trait, cob yield plant $^{-1}$ had recorded positive and significant association with kernel yield plant ${ }^{-}$ ${ }^{1}$ followed by cob length and cob girth at both genotypic and phenotypic levels.

These results are in agreement with the findings of Bisen et al., (2018). Whereas, the traits like kernel rows $\mathrm{cob}^{-1}$ and kernels row ${ }^{-1}$ exhibited significant and positive association at phenotypic level. These results are in agreement with the reports of Bikal and Timsina (2015). Further, the traits, namely, plant height and ear placement height recorded significant and positive correlation coefficients values with kernel yield per plant at genotypic level. The results are in conformity with the findings of Lad et al., (2018) and Grace et al., (2018). The trait, anthesis silking interval alone had however, recorded significant and negative correlation at genotypic level.

Association analysis among yield contributing traits, revealed positive and significant association of days to 50 per cent tasseling with days to 50 per cent silking, days to maturity, plant height and ear placement height; days to 50 per cent silking with days to maturity, plant height and ear placement height; days to maturity with plant height and ear placement height; plant height with ear placement height, cob length, 100 kernel weight and cob yield plant ${ }^{-1}$; cob length with cob girth and cob yield plant ${ }^{-1}$; cob girth with cob yield plant $^{-1}$ and 100 kernel weight; and kernels row $^{-1}$ with cob yield plant ${ }^{-1}$ at both genotypic level and phenotypic levels. Similar results were observed earlier by Lad et al., (2018). 
Table.1 Phenotypic (above the diagonal) and genotypic (below the diagonal) correlations among kernel yield and its attributing characters in maize (Zea mays L.)

\begin{tabular}{|c|c|c|c|c|c|c|c|c|c|c|c|c|c|c|}
\hline Character & DT & DS & ASI & DM & $\mathbf{P H}$ & EPH & $\mathbf{C L}$ & CG & KR & KPR & CYP & $100 \mathrm{KW}$ & $\mathbf{P C}$ & KYP \\
\hline DT & 1.0000 & $0.9969^{* *}$ & 0.0077 & $0.9135^{* *}$ & $0.4206^{* *}$ & $0.2415^{*}$ & 0.0830 & 0.0482 & 0.0599 & 0.1349 & 0.0310 & 0.0981 & $-0.2075^{*}$ & 0.0229 \\
\hline DS & $0.9997^{* *}$ & 1.0000 & 0.0331 & $0.9126^{* *}$ & $0.4080^{* *}$ & $0.2232^{*}$ & 0.0708 & 0.0342 & 0.0334 & 0.1335 & 0.0198 & 0.0988 & $-0.2044^{*}$ & 0.0201 \\
\hline ASI & 0.0957 & 0.0942 & 1.0000 & 0.0029 & $-0.2373^{*}$ & $-0.2696^{* *}$ & -0.0956 & -0.0790 & -0.1795 & 0.0405 & -0.0109 & -0.0200 & 0.0120 & 0.0511 \\
\hline DM & $0.9685^{* *}$ & $0.9609^{* *}$ & -0.0159 & 1.0000 & $0.4803^{* *}$ & $0.2984^{*}$ & 0.0755 & 0.0541 & 0.0774 & 0.0487 & 0.0258 & 0.1801 & $-0.2828^{* *}$ & 0.0149 \\
\hline PH & $0.4824^{* *}$ & $0.4675^{* *}$ & $-0.4465^{* *}$ & $0.5590^{* *}$ & 1.0000 & $0.7143^{* *}$ & $0.2743^{* *}$ & 0.1066 & -0.0127 & 0.1841 & $0.2555^{*}$ & $0.3305^{* *}$ & -0.1847 & 0.1944 \\
\hline EPH & $0.2832^{* *}$ & $0.2639^{* *}$ & $-0.5649^{* *}$ & $0.3596^{* *}$ & $0.8182^{* *}$ & 1.0000 & 0.1772 & 0.0007 & 0.0502 & 0.1062 & $0.2257^{*}$ & 0.1681 & -0.1074 & 0.1120 \\
\hline CL & 0.1424 & 0.1169 & $-0.2837^{* *}$ & 0.0760 & $0.4322^{* *}$ & $0.3977^{* *}$ & 1.0000 & $0.4687^{* *}$ & -0.0395 & $0.3595^{* *}$ & $0.5218^{* *}$ & -0.0059 & 0.0399 & $0.5212^{* *}$ \\
\hline CG & 0.0206 & 0.0062 & -0.0814 & 0.0031 & $0.2038^{*}$ & 0.0199 & $0.3191^{* *}$ & 1.0000 & 0.1557 & 0.1757 & $0.6016^{* *}$ & $0.2140^{*}$ & 0.0284 & $0.6082^{* *}$ \\
\hline KR & 0.0513 & 0.0230 & $-0.6644^{* *}$ & 0.0692 & 0.1051 & 0.0138 & -0.1295 & 0.1329 & 1.0000 & -0.0079 & $0.2525^{*}$ & -0.1093 & -0.1380 & $0.2167^{*}$ \\
\hline KPR & $0.2149^{*}$ & $0.2136^{*}$ & 0.1295 & 0.0662 & $0.2931^{* *}$ & 0.1811 & $0.2940^{* *}$ & -0.0801 & $-0.3225^{* *}$ & 1.0000 & $0.4841^{* *}$ & -0.0440 & -0.0375 & $0.4068^{* *}$ \\
\hline CYP & 0.1158 & 0.0924 & $-0.3388^{* *}$ & 0.1289 & $0.5946^{* *}$ & $0.4086^{* *}$ & $0.4734^{* *}$ & $0.8437^{* *}$ & 0.0863 & $0.2320^{*}$ & 1.0000 & 0.1691 & -0.0411 & $0.9308^{* *}$ \\
\hline $100 \mathrm{KW}$ & 0.1596 & 0.1555 & 0.0949 & $0.3409^{* *}$ & $0.4676^{* *}$ & $0.2703^{* *}$ & -0.1265 & $0.3697^{* *}$ & $-0.3151^{* *}$ & -0.1857 & $0.3734^{* *}$ & 1.0000 & -0.0345 & 0.1098 \\
\hline PC & $-0.2920^{* *}$ & $-0.2961^{* *}$ & 0.1605 & $-0.4514^{* *}$ & $-0.3219^{* *}$ & -0.1156 & 0.0977 & $0.2112^{*}$ & $-0.4513^{* *}$ & $-0.2342^{*}$ & 0.0036 & -0.0124 & 1.0000 & 0.0291 \\
\hline KYP & 0.1069 & 0.0880 & $-0.2715^{* *}$ & 0.0795 & $0.4176^{* *}$ & $0.2033^{*}$ & $0.4147^{* *}$ & $0.8235^{* *}$ & 0.0315 & 0.0550 & $0.8826^{* *}$ & 0.1575 & 0.1481 & 1.0000 \\
\hline
\end{tabular}

* Significant at 5 per cent level ${ }^{* *}$ Significant at 1 per cent level

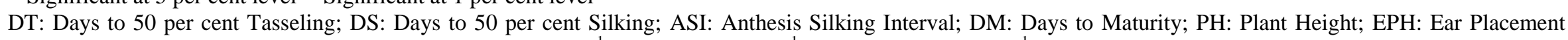

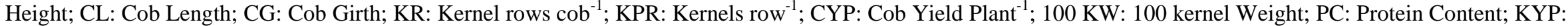
Kernel Yield Plant ${ }^{-1}$ 
Table.2 Direct (diagonal) and indirect effects (above and below the diagonal) of different traits on kernel yield per plant in maize (Zea mays L.)

\begin{tabular}{|c|c|c|c|c|c|c|c|c|c|c|c|c|c|c|c|}
\hline Character & & DT & DS & ASI & DM & PH & EPH & CL & CG & KR & KPR & CYP & $100 \mathrm{GW}$ & PC & GYP \\
\hline \multirow[t]{2}{*}{ DT } & $\mathbf{G}$ & -4.2147 & 5.2070 & 0.0312 & -0.9718 & 0.1258 & -0.0586 & -0.0029 & -0.0156 & -0.0095 & -0.1903 & 0.2434 & -0.0747 & 0.0375 & 0.1069 \\
\hline & $\mathbf{P}$ & -1.1591 & 1.1658 & 0.0003 & 0.0023 & 0.0362 & -0.0280 & 0.0036 & 0.0027 & 0.0009 & -0.0108 & 0.0292 & -0.0070 & -0.0132 & 0.0229 \\
\hline \multirow[t]{2}{*}{ DS } & $\mathbf{G}$ & -4.2135 & 5.2086 & 0.0307 & -0.9641 & 0.1219 & -0.0546 & -0.0024 & -0.0047 & -0.0043 & -0.1892 & 0.1941 & -0.0728 & 0.0380 & 0.0880 \\
\hline & $\mathbf{P}$ & -1.1555 & 1.1695 & 0.0011 & 0.0023 & 0.0351 & -0.0259 & 0.0031 & 0.0019 & 0.0005 & -0.0106 & 0.0186 & -0.0070 & -0.0130 & 0.0201 \\
\hline \multirow[t]{2}{*}{ ASI } & G & -0.4032 & 0.4907 & 0.3260 & 0.0159 & -0.1165 & 0.1168 & 0.0058 & 0.0613 & 0.1232 & -0.1147 & -0.7119 & -0.0444 & -0.0206 & $-0.2715^{* *}$ \\
\hline & $\mathbf{P}$ & -0.0090 & 0.0387 & 0.0332 & 0.0001 & -0.0204 & 0.0313 & -0.0042 & -0.0044 & -0.0028 & -0.0032 & -0.0103 & 0.0014 & 0.0008 & 0.0511 \\
\hline \multirow[t]{2}{*}{ DM } & G & -4.0822 & 5.0047 & -0.0052 & -1.0034 & 0.1458 & -0.0744 & -0.0016 & -0.0024 & -0.0128 & -0.0586 & 0.2710 & -0.1595 & 0.0580 & 0.0795 \\
\hline & $\mathbf{P}$ & -1.0588 & 1.0673 & 0.0001 & 0.0025 & 0.0413 & -0.0346 & 0.0033 & 0.0030 & 0.0012 & -0.0039 & 0.0243 & -0.0128 & -0.0179 & 0.0149 \\
\hline \multirow[t]{2}{*}{ PH } & G & -2.0330 & 2.4349 & -0.1456 & -0.5609 & 0.2608 & -0.1692 & -0.0088 & -0.1537 & -0.0195 & -0.2595 & 1.2495 & -0.2188 & 0.0414 & $0.4176^{* *}$ \\
\hline & $\mathbf{P}$ & -0.4875 & 0.4771 & -0.0079 & 0.0012 & 0.0860 & -0.0829 & 0.0120 & 0.0060 & -0.0002 & -0.0147 & 0.2405 & -0.0235 & -0.0117 & 0.1944 \\
\hline \multirow[t]{2}{*}{ EPH } & G & -1.1936 & 1.3743 & -0.1842 & -0.3608 & 0.2134 & -0.2068 & -0.0081 & -0.0150 & -0.0026 & -0.1604 & 0.8586 & -0.1265 & 0.0149 & $0.2033^{*}$ \\
\hline & $\mathbf{P}$ & -0.2799 & 0.2610 & -0.0089 & 0.0007 & 0.0614 & -0.1161 & 0.0077 & 0.0000 & 0.0008 & -0.0085 & 0.2124 & -0.0120 & -0.0068 & 0.1120 \\
\hline \multirow[t]{2}{*}{ CL } & $\mathbf{G}$ & -0.6000 & 0.6089 & -0.0925 & -0.0763 & 0.1127 & -0.0822 & -0.0205 & -0.2406 & 0.0240 & -0.2604 & 0.9948 & 0.0592 & -0.0126 & $0.4147^{* *}$ \\
\hline & $\mathbf{P}$ & -0.0962 & 0.0828 & -0.0032 & 0.0002 & 0.0236 & -0.0206 & 0.0436 & 0.0262 & -0.0006 & -0.0287 & 0.4911 & 0.0004 & 0.0025 & $0.5212^{* *}$ \\
\hline \multirow[t]{2}{*}{ CG } & $\mathbf{G}$ & -0.0870 & 0.0324 & -0.0265 & -0.0031 & 0.0532 & -0.0041 & -0.0065 & -0.7540 & -0.0246 & 0.0709 & 1.7731 & -0.1730 & -0.0271 & $0.8235^{* *}$ \\
\hline & $\mathbf{P}$ & -0.0559 & 0.0400 & -0.0026 & 0.0001 & 0.0092 & -0.0001 & 0.0204 & 0.0558 & 0.0024 & -0.0140 & 0.5662 & -0.0152 & 0.0018 & $0.6082^{* *}$ \\
\hline \multirow[t]{2}{*}{ KR } & $\mathbf{G}$ & -0.2160 & 0.1196 & -0.2166 & -0.0694 & 0.0274 & -0.0028 & 0.0026 & -0.1002 & -0.1854 & 0.2856 & 0.1814 & 0.1475 & 0.0580 & 0.0315 \\
\hline & $\mathbf{P}$ & -0.0694 & 0.0390 & -0.0060 & 0.0002 & -0.0011 & -0.0058 & -0.0017 & 0.0087 & 0.0154 & 0.0006 & 0.2376 & 0.0078 & -0.0087 & $0.2167^{*}$ \\
\hline \multirow[t]{2}{*}{ KPR } & G & -0.9059 & 1.1127 & 0.0422 & -0.0664 & 0.0764 & -0.0375 & -0.0060 & 0.0604 & 0.0598 & -0.8855 & 0.4876 & 0.0869 & 0.0301 & 0.0550 \\
\hline & $\mathbf{P}$ & -0.1563 & 0.1562 & 0.0013 & 0.0001 & 0.0158 & -0.0123 & 0.0157 & 0.0098 & -0.0001 & -0.0798 & 0.4556 & 0.0031 & -0.0024 & $0.4068^{* *}$ \\
\hline \multirow[t]{2}{*}{ CYP } & G & -0.4882 & 0.4810 & -0.1104 & -0.1294 & 0.1551 & -0.0845 & -0.0097 & -0.6361 & -0.0160 & -0.2055 & 2.1015 & -0.1747 & -0.0005 & $0.8826^{* *}$ \\
\hline & $\mathbf{P}$ & -0.0359 & 0.0231 & -0.0004 & 0.0001 & 0.0220 & -0.0262 & 0.0228 & 0.0336 & 0.0039 & -0.0386 & 0.9411 & -0.0120 & -0.0026 & $0.9308^{* *}$ \\
\hline \multirow[t]{2}{*}{$100 \mathrm{GW}$} & G & -0.6725 & 0.8100 & 0.0310 & -0.3421 & 0.1220 & -0.0559 & 0.0026 & -0.2787 & 0.0584 & 0.1644 & 0.7847 & -0.4679 & 0.0016 & 0.1575 \\
\hline & $\mathbf{P}$ & -0.1137 & 0.1156 & -0.0007 & 0.0004 & 0.0284 & -0.0195 & -0.0003 & 0.0119 & -0.0017 & 0.0035 & 0.1591 & -0.0713 & -0.0022 & 0.1098 \\
\hline \multirow[t]{2}{*}{ PC } & G & 1.2307 & -1.5424 & 0.0523 & 0.4529 & -0.0840 & 0.0239 & -0.0020 & -0.1592 & 0.0837 & 0.2074 & 0.0075 & 0.0058 & -0.1285 & 0.1481 \\
\hline & $\mathbf{P}$ & 0.2405 & -0.2390 & 0.0004 & -0.0007 & -0.0159 & 0.0125 & 0.0017 & 0.0016 & -0.0021 & 0.0030 & -0.0387 & 0.0025 & 0.0634 & 0.0291 \\
\hline
\end{tabular}

P: Phenotypic level G: Genotypic level Residual effect at genotypic level $=0.1247 \quad$ Residual effect at phenotypic level $=0.3164$

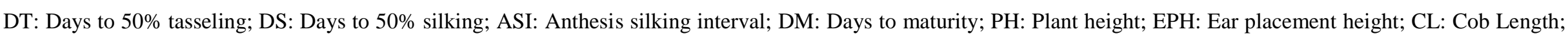

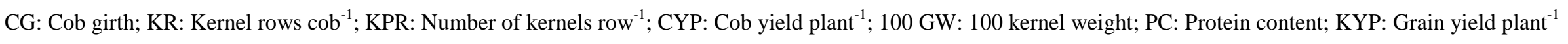


Fig.1 Genotypic path diagram showing direct and indirect effects of yield components on kernel yield plant $^{-1}$ in maize (Zea mays L.)

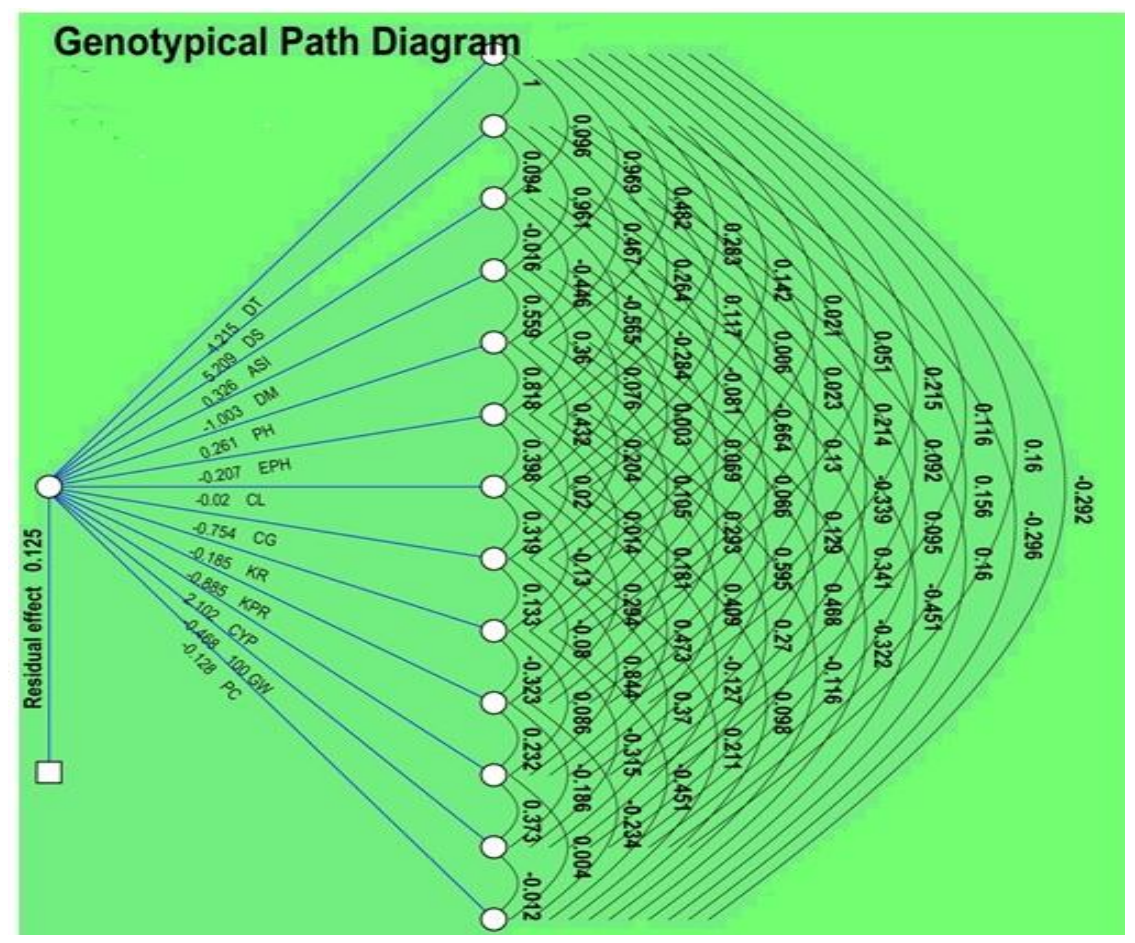

Fig.2 Phenotypic path diagram showing direct and indirect effects of yield components on kernel yield plant ${ }^{-1}$ in maize (Zea mays L.)

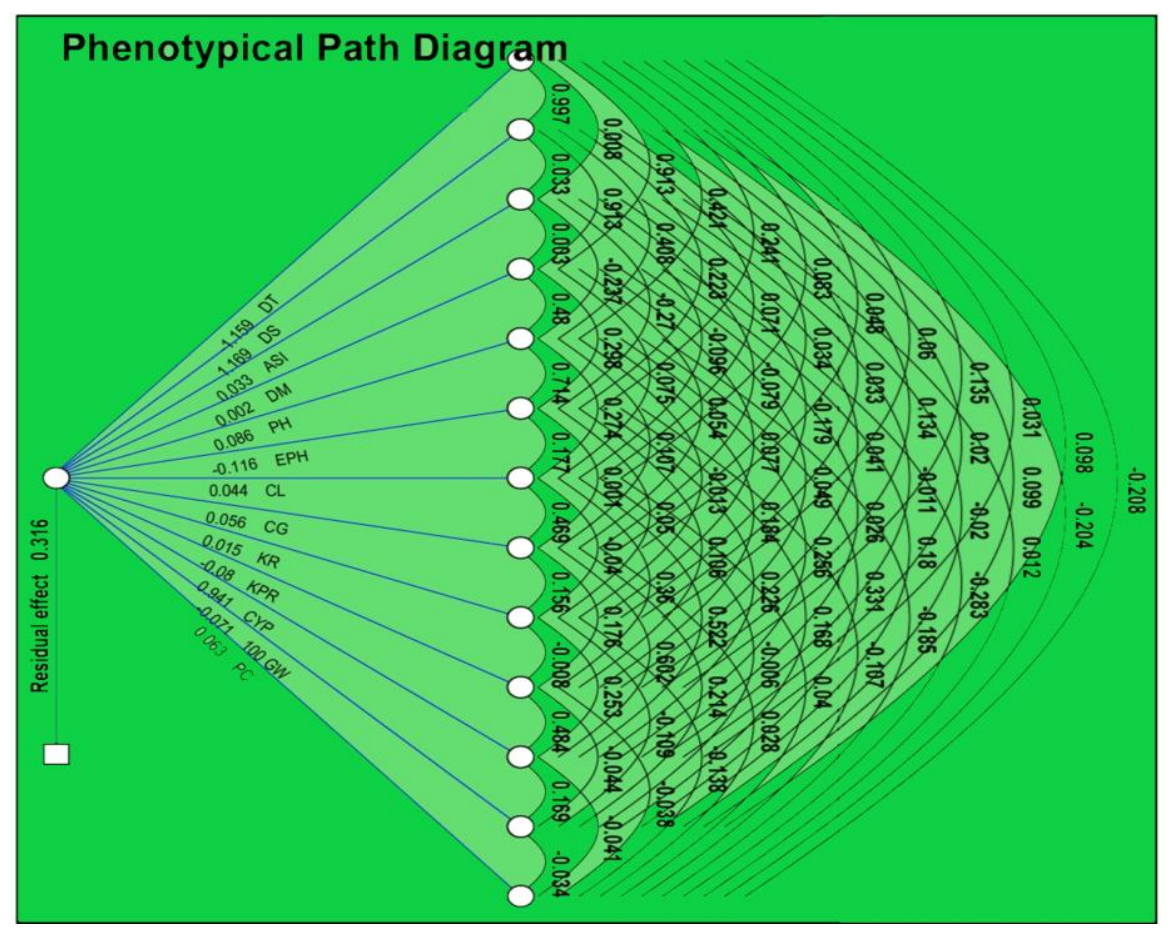


The analysis also revealed negatively significant inter-character association of protein content with days to 50 percent tasseling, days to 50 percent silking and days to maturity. These results are in consonance with the findings of Sukumar et al., (2018) and Lad et al., (2018). Association of anthesis silking interval with plant height and ear placement height was also noticed to be significant and negative at both genotypic and phenotypic levels, indicating the need for balanced selection, while effecting improvement for these traits.

The characters, namely cob length, cob girth and cob yield plant ${ }^{-1}$ had exhibited significant and positive correlation at both genotypic and phenotypic level with kernel yield and hence may be considered as important selection criteria for kernel yield improvement in maize.

\section{Path analysis}

Estimates of direct and indirect effects of individual characters towards kernel yield are presented in Table 2 and Figures 1 \& 2. A perusal of the results revealed residual effect of 0.1247 at genotypic level and 0.3164 percent at phenotypic level, indicating that 87.53 percent and 68.36 percent of the variability in the dependent variable, kernel yield plant ${ }^{-1}$ was explained by the independent variable or traits studied in the present investigation at genotypic and phenotypic levels, respectively.

The path coefficient analysis revealed high positive direct effect of cob yield yield plant ${ }^{1}$ for kernel yield at both genotypic and phenotypic levels coupled with positive and significant association of the trait with kernel yield per plant indicating its importance as effective selection criteria for kernel yield improvement in maize. The results are in agreement with the findings of Gazal et al.,
2018. However, days to 50 percent silking recorded non-significant positive direct effect (Grace et al., 2018). Further, the traits like cob yield per plant, cob girth and kernel rows $\mathrm{cob}^{-1}$ at phenotypic level and anthesis silking interval and plant height at genotypic level had exhibited significant positive direct effects on kernel yield per plant. The results of plant height are in agreement with the findings of Grace et al., (2018) and those of anthesis silking interval with reports of Kumar et al., (2017).

The traits cob length, $\left(\mathrm{p}_{\mathrm{p}}=0.0436\right)$ and cob girth $\left(\mathrm{p}_{\mathrm{p}}=0.0558\right)$ exhibited low direct effects but strong correlation with grain yield due to the high indirect effect via cob yield plant $^{-1}$. Similar results were reported by Lakshmi et al., (2018) and Sukumar et al., (2018). Futher, significant negative direct effect was exhibited by the trait number of kernels row ${ }^{-1}$ $\left(\mathrm{p}_{\mathrm{p}}=-0.0798\right.$ and $\left.\mathrm{p}_{\mathrm{g}}=-0.8855\right)$ for kernel yield plant ${ }^{-1}$ via indirect effect through 100 kernel weight $\left(p_{p}=0.003\right.$ and $\left.p_{g}=0.2074\right)$. Similar findings were reported earlier by Nirmal et al., (2018).

The results of path coefficient analysis thus revealed the importance of cob yield per plant for genetic improvement of the kernel yield plant $^{-1 .}$

In conclusion the studies on character association and path coefficient for kernel yield per plant and yield component characters revealed the importance of cob yield per plant $^{-1}$ in improvement of kernel yield plant ${ }^{-1}$. Hence, cob yield per plant $^{-1}$ is identified as an effective selection crioteria for kernel yield improvement in maize.

\section{References}

Bikal, G and Timsina, D. 2015. Analysis of yield and yield attributing traits of maize genotypes in Chitwan, Nepal. World Journal of Agricultural Research.3 (5): 
153-162.

Bisen, N., Rahangdale, C.P and Sahu, R.P. 2018. Genetic variability and correlation studies of yield and yield component in maize hybrids (Zea mays 1.) under kymore plateau and satpura hill region of madhya pradesh. International Journal of Agriculture, Environment and Biotechnology. 11 (1): 71-77.

Dewey, D and Lu, K.H. 1959. A correlation and path coefficient analysis of components of crested wheat grass seed production. Agronomy Journal. 51: 515-518.

Falconer, D.S. 1964. An Introduction to Quantitative Genetics. Oliver and Boyd Publishing Co. Pvt. Ltd., Edinburgh. 312324.

Gazal, A., Dar, Z.A., Lone, A.A., Yousuf, N and Gulzar, S. 2018. Studies on maize yield under drought using correlation and path coefficient analysis. International Journal of Current Microbiology and Applied Science. 7 (1): 516-521.

Grace, B., Marker, S and Rajasekhar, D. 2018. Assessment of quantitative genetic variability and character association in maize (Zea mays L.). Journal of Pharmacognosy and Phytochemistry. 7 (1): 2813-2816.

Kumar, R., Dubey, R.B., Ameta, K.D., Kunwar, R., Verma, R and Bisen, P. 2017. Correlation and path coefficient analysis for yield contributing and quality traits in quality protein maize (Zea mays L.). International Journal of Current Microbiology and Applied Sciences. 6 (10): 2139-2146.
Lad, D.B., Borle, U.M and Dhumal, N.U. 2018. Studies on genetic variability, association of characters and path analysis in maize (Zea mays L.) inbreds. International Journal of Pure \& Applied Bioscience. 6 (4): 241-245.

Lakshmi, M.S., Jagadev, P.N., Das, S., Lenka, D., Swain, D and Tripathy, S.K. 2018. Genetic variability and association analysis of maize hybrids under excessive soil moisture condition. International Journal of Current Microbiology and Applied Science. 7 (9): 2935-2941.

Lenka, D and Mishra, B. 1973. Path coefficient analysis of yield in rice varieties. Indian Journal of Agricultural Sciences. 43:376379.

Lokeshwar Reddy, A., Srinivas, T., Prasanna Rajesh, A and Uma maheswari P. 2018. Genetic variability and association anlysis for yield and yield component traits in groundnut. Green farming. 9(4). 586-590.

Nirmal, R.R., Renuka, D.C.P and Gokulakrishnan, J. 2018. Indirect selection for various yield attributing characters of maize hybrids across environments using correlation and path analysis. Journal of Pharmacognosy and Phytochemistry. 7 (5): 1810-1812.

Sukumar, K., Hemalatha, V., Reddy, N.V and Reddy, S.N. 2018. Correlation and path analysis studies for yield and quality traits in quality protein maize (Zea mays L.). International Journal of Current Microbiology and Applied Sciences. 7 (4): 3846-3854.

\section{How to cite this article:}

Mallikarjuna, S., V. Roja, I. Sudhir Kumar and Srinivas, T. 2020. Correlation and Path Coefficient Studies for Kernel Yield and Component Traits in Maize. Int.J.Curr.Microbiol.App.Sci. 9(08): 168-174. doi: https://doi.org/10.20546/ijcmas.2020.908.018 